\title{
Appendix Small Cell Carcinoma
}

National Cancer Institute

\section{Source}

National Cancer Institute. Appendix Small Cell Carcinoma. NCI Thesaurus. Code C43555.

An aggressive, poorly differentiated neuroendocrine malignant neoplasm arising from the wall of the appendix. It is characterized by the presence of small malignant cells, necrotic changes, and an increased mitotic rate. 